\title{
Detection of Cytotoxicity and Carcinogenicity of Soft Drink "Cola" on Allium Cepa Root Cells
}

\author{
Ekhlas Mohammed Farhan ${ }^{1}$, and Rana Fawzi Tawfiq ${ }^{2}$
}

\begin{abstract}
The present investigation had been conducted to study the cytogenetic effects of soft drink "cola " at concentration (100\%) with three exposure times $(4,6$, and 8 hours) on root meristems of Allium cepa. The parameters tested were: mitotic index and chromosomal aberrations. Mitotic index was reduced in all exposure times 4,6 and $8 \mathrm{~h}$ with cola. On the other hand, total chromosomal abnormalities were highly increased in all exposure times comparatively with control. The physiological chromosomal aberrations observed were: (c-mitosis, stickiness, disturbance and laggard chromosome; and clastogenic aberrations were: chromosomal break and bridges. These findings indicate the cytotoxicity and carcinogenicity of the soft drink "cola". Our results supports the calls for warned for excessive intake of soft drinks especially "cola".
\end{abstract}

Keywords-soft drink, carcinogenicity, mitotic index , chromosomal aberration, Allium cepa test.

\section{INTRODUCTION}

S OFT drinks are nonalcoholic water based flavored drinks that are optionally sweetened, acidulated, carbonated and may contain fruit, fruit juice and /or salts; their flavor may derive from vegetable extracts or other aromatic substances (Chandraker et al., 2014). Cola-flavored drinks are the most widely recognized and consumed soft drinks globally (Rayes, 2008). The most common soft drink ingredients are water, sugar, fruit concentrate, acidulants such as phosphoric acid, antioxidants, preservatives, sweeteners, caffeine, carbon dioxide, in addition to caramel which is the main color additive in Cola (Düsman et al., 2013).

Researches have shown that soft drink consumption, particularly Cola flavored soft drinks, can cause dental erosion and reduce hardness of tooth enamel (Jensdottira et al., 2005; Wongkhantee et al., 2006).

Regular cola drinking resulted in hyperglycemia which largely accounted for the observed increase in the non-HDL cholesterol fraction in mice (Otero-Losada et al., 2013). 2Methylimidazole (2MI) and 4-methylimidazole(4MI) have been identified as undesirable by-products in several food products, including caramel coloring, soy sauce, Worcestershire sauce, wine, ammoniated molasses, and caramel-colored syrups (NTP).4-Methylimidazole has received the attention of federal and state regulatory agencies because of its carcinogenicity and common presence in foods

Ekhlas Mohammed Farhan, (Corresponding author)

Msc. food science, Ministry of Science \& Technolog, Baghdad, Iraq.

Rana Fawzi Tawfiq ${ }^{2}$, Msc. Immunology, Ministry of Science \& Technology, Baghdad, Iraq. and beverages found in commercial cola soft drinks (Moon and Shibamoto , 2011) and carcinogenic activity of 2MI (2Methylimidazole) was demonstrated in male and female rats and mice (Chan et al., 2008), furthermore, metabolic and cardiovascular alterations associated with cola drinking in normal rats was reported (Milei et al., 2011).

Caramel coloring can cause convulsions when administered to rats, mice, and chickens, and it adversely affected the levels of white blood cells (lymphocytes) in laboratory animals. Also it can inhibit the absorption of vitamin B6 in rabbits due to the presence of 4-Methylimidazol (Düsman et al., 2013).

The U.S. National Toxicology Program (NTP) assessed the carcinogenicity of 4-MEI in male and female mice and rats using two-year feeding studies in 2007, concluding that there wasa clear evidence of carcinogenic activity in male and female mice and equivocal evidence of carcinogenic activity in female rats, based on increases lung adenomas and carcinomas in exposed mice and increases in leukemia in exposed female rats relative to controls (NTP, 2007).Another ingredient present in cola soft drinks that can induce mutagenic activity is caffeine. Different concentrations of caffeine induced an increase in the percentage of micronuclei and aberrant metaphases, and the rate of chromosomal abnormalities (Choudhury and Palo, 2004). Caffeine also causes changes the DNA repair system, which leads to diseases in various organs, especially cardiovascular abnormalities and pancreatic cancer (Ito et al., 2003; Keast and Riddell, 2007).

The Allium cepa test is an easy and fast genetic assay to detect the potential cytotoxicity and genotoxicity of polluted water and other chemical substances on mitosis and chromosomes structure of Allium cepa cells through the analysis of root morphology, mitotic index and chromosomal aberration of Allium cepa root tips (Akinboro, 2011; Adeyemo and Farinmade, 2013).

\section{MATERIALS AND METHODS}

Dry healthy white A. cepa bulbs of 1.5 to $2.0 \mathrm{~cm}$ in diameter were purchased from local markets. The outer papery brown layer of each onion was peeled away and the dried basal root plate was cleaned. The onions were placed in tubes filled with distilled water at room temperature and the root growth was observed till reached $1.5-2 \mathrm{~cm}$ in length, then the bulbs placed in $100 \%$ cola soft drink for 4,6,8 hours respectively as well as the control bulbs treated with distilled water. The root tips were fixed in fixative (ethanol: acetic acid, $3: 1 \mathrm{v} / \mathrm{v}$ ) for $90 \mathrm{~min}$, hydrolyzed in $1 \mathrm{~N} \mathrm{HCL}$, stained in $1 \%$ aceto-orcein stain and squashed in $45 \%$ glacial acid on 
microscope slides. For microscopic studies, mitotic stages and chromosomal aberrations in Allium root cells were determined using light microscope (Adeyemo and Farinmade, 2013).

\section{RESULT AND DISCUSSION}

\section{A. Effect of soft drink (Coca-cola) on mitotic index (MI)}

Coca cola has decreased MI in the treatment groups compared with the control at all treatment periods (Table1). Mitotic index decline in Allium cepa root cells with the increasing of the treatment periods with coca colamay reflect coca cola cytotoxicity through the inhibition of cells cycle from the $\mathrm{S}$ (Synthesis) phase to the $\mathrm{M}$ (Mitosis) phase, or might be due to the prevention of DNA synthesis and holding the cell from entering mitosis (Karaismailoglu , 2014).

TABLE 1

MitotiC INDEX (MI) IN ALLIUM CEPA ROOT CELLS TREATED WITH COCA COLA

\begin{tabular}{ccc}
\multicolumn{3}{c}{ IN DIFFERENT TREATMENT DURATION: } \\
\hline \hline & Time of & Mitotic \\
Treatments & Treatment & Index(Mean \pm SE)
\end{tabular}
(h)

\begin{tabular}{ccc}
\multicolumn{3}{c}{$(\mathrm{h})$} \\
\hline & & \\
Control & 4 & 13.6 \\
(Distilled & 6 & 10.0 \\
water) & 8 & 8.5 \\
& 4 & $4.72^{*}$ \\
Coca -cola & 6 & $2.25^{* *}$ \\
& 8 & $1.132^{* * *}$ \\
\hline
\end{tabular}

- ${ }^{*}$ Significantly different $(\mathrm{P}<0.05)$ from the control group

- ${ }^{* *} \mathrm{P}<0.01$

- ${ }^{* * * *} \mathrm{P}<0.001$

\section{B. Frequency of mitotic phases}

After the treatment with Coca cola at $100 \%$ for 4,6 and $8 \mathrm{~h}$ respectively, the frequency of the mitotic phases is approximately identical in both variants of treatment (Table 2). The higher frequency is for prophases, followed by metaphases, telophases and anaphases respectively. The decrement of all four division phases may reflect that cola affects the normal development of whole mitotic process.

TABLE II

PHASES OF MITOTIC DIVISION IN ALLIUM CEPA ROOT CELLS AFTER THE TREATMENT WITH COCA COLA

\begin{tabular}{|c|c|c|c|c|c|c|c|c|c|c|c|}
\hline \multirow[t]{2}{*}{ Treatments } & \multirow[t]{2}{*}{$\begin{array}{c}\text { Time of } \\
\text { Treatme } \\
\text { nt (h) }\end{array}$} & \multirow{2}{*}{$\begin{array}{l}\text { Total } \\
\text { no. of } \\
\text { cells } \\
\text { examin } \\
\text { ed } \\
\end{array}$} & \multirow[t]{2}{*}{$\begin{array}{c}\text { Total } \\
\text { Mitosis }\end{array}$} & \multirow[t]{2}{*}{$\begin{array}{l}\text { Mitotic } \\
\text { index }\end{array}$} & \multicolumn{2}{|c|}{ Prophases } & \multicolumn{2}{|c|}{ Mataphases } & \multicolumn{2}{|c|}{ Anaphases } & \multirow{2}{*}{$\begin{array}{l}\text { Telop } \\
\text { No }\end{array}$} \\
\hline & & & & & No. & $\%$ & No & $\%$ & No & $\%$ & \\
\hline \multirow{4}{*}{ Control } & 4 & 1000 & 103 & 10.3 & 52 & 50.48 & 16 & 24.09 & 22 & 19.277 & 13 \\
\hline & 6 & 768 & 100 & 13.02 & 41 & 41 & 23 & 23 & 16 & 16 & 20 \\
\hline & 8 & 855 & 88 & 10.29 & 30 & 34.09 & 12 & 13.63 & 24 & 27.27 & 22 \\
\hline & 4 & 578 & 32 & 5.5 & 11 & 37.5 & 7 & 21.875 & 5 & 15.625 & 8 \\
\hline \multirow[t]{2}{*}{ Coca-cola } & 6 & 635 & 25 & 3.39 & 8 & 32 & 5 & 20 & 7 & 28 & 5 \\
\hline & 8 & 856 & 20 & 2.33 & 8 & 40 & 3 & 15 & 3 & 15 & 6 \\
\hline
\end{tabular}

Our results are compatible to results were found by Hannah et al (2010) studying cytotoxicity of Coke and Pepsi soft drinks, which exhibited the inhibitory effect of mitosis by the calculation of the mitotic index in Allium cepa roots treated for 2, 24, and 48 hours.

\section{Chromosomal aberration}

Coca-cola induced significant increasing in the frequencies of aberrant cells compared with the water treated group (control). The number of aberrant cell increased with an increase in the duration of treatment with the test substance used (Table 3).

TABLE III

TOTAL NUMBER OF ABERRANT CELL IN ALLIUM CEPA ROOT CELLS TREATED WITH COCA-COLA:

\begin{tabular}{ccc}
\hline Treatments & $\begin{array}{c}\text { Time of } \\
\text { Treatment (h) }\end{array}$ & $\begin{array}{c}\text { No. of aberrant cells } \\
\text { calculated in 100 dividing } \\
\text { cells }\end{array}$ \\
\hline Control & 4 & 1 \\
& 6 & 4 \\
& 8 & 5 \\
Coca-cola & 4 & 43 \\
& 6 & 48 \\
\hline
\end{tabular}

Coca-cola at $100 \%$ concentration induced different kinds of chromosomal aberrations such as c-mitosis, stickiness, bridges, disturbed chromosomes, clumped chromosomes, granulate nucleus, karyorrhectic nucleus, laggard chromosomes, and clastogenic chromosomal breaks in all durations of treatment ( Table 4 ) (figure 1).

The most frequent aberration seen is stickiness of chromosomes $(\mathrm{P}<0.01)$. It resulted from increased chromosomal contraction and condensation or might from the depolymerization of the DNA and partial dissolution of nucleoproteins. It reflects the toxic effects of the tested materials, and it is usually irreversible and may leads to cell death. This may explain the abundant numbers of ghost cells that found in coca-cola treated root cells (data not shown), specially observed in the duration of treatment in 6 and $8 \mathrm{~h}$. Ghost cell is a dead cell in which the outline is visible but nucleus and cytoplasmic structure is not stainable (Khanna and Sharma, 2013).

Clastogenic aberrations that found to induce by coca-cola are anaphase chromosome bridges and chromosome breakage .Chromosome bridges could be attributed to chromosomal stickiness, and to chromosome breakage and reunion. Chromosomal bridges could happen during the translocation of the unequal chromatid exchange or due to dicentric chromosomes caused by structural chromosome mutations. Induction of bridges and breaks may lead to loss of genetic material (Sudhakar et al., 2001; Neelamkavil and Thoppil, 2014). This may reflects the potential ${ }_{2}^{14}$ carcinogenic and mutagenic effects of Coca cola through ${ }_{25}^{25}$ ncrement of chromosomal alterations (Düsman et al., 2013). It ${ }_{20}^{25}$ Was also observed that there was gradual decrease in the 3number of chromosome aberrations with increase duration of treatment. Suggesting cell cycle arresting that most cells in prophase. This reflects the direct proportional toxicity with time exposure. It was also noted a very rare aberration (tied chromosome) (fig. 1-d) in exposure to coca-cola at $6 \mathrm{hr}$, this may explained by either there is duplication in chromosome length and stickiness of its end other chromosome in the equatorial plate; or stickiness of two chromosomes end to form a tie shape. 
High potential of genotoxicity for Coca cola in our research, matches the findings of other authors, who did researches on mutagenic effects of Coca cola on animals and Allium cepa test (Düsman et al., 2013; Chandraker et al., 2014). However there is only limited research available on its genotoxic and /or carcinogenic potential in humans.

TABLE IV

CHROMOSOMAL ABERRATIONS IN ALLIUM CEPA ROOT CELLS AFTER THE TREATMENT WITH COCA- COLA

\begin{tabular}{|c|c|c|c|c|c|c|c|c|c|c|c|}
\hline \multirow[t]{2}{*}{ Treatments } & \multirow{2}{*}{$\begin{array}{c}\text { Time of } \\
\text { Treatment } \\
\text { (h) }\end{array}$} & \multicolumn{9}{|c|}{ Chromosomal aberrations per 100 cell } & \multirow{2}{*}{$\begin{array}{c}\text { Total } \\
\text { Aberrant } \\
\text { cells }\end{array}$} \\
\hline & & Bridge & Break & Lag & $\mathrm{Cm}$ & St. & $\mathrm{Cl}$. & Dis. & Gran. & Frag. & \\
\hline \multirow[t]{3}{*}{ Control } & 4 & 0 & 0 & 1 & 0 & 0 & 0 & 0 & 0 & 0 & 0.01 \\
\hline & 6 & 1 & 0 & 0 & 0 & 1 & 1 & 0 & 1 & 0 & 0.04 \\
\hline & 8 & 1 & 0 & 1 & 1 & 2 & 0 & 0 & 0 & 0 & 0.05 \\
\hline \multirow[t]{3}{*}{ Coca -cola } & 4 & 1 & 0 & 2 & 1 & 16 & 9 & 2 & 10 & 2 & $0.43^{* *}$ \\
\hline & 6 & 2 & 1 & 3 & - & 20 & 8 & 5 & 9 & - & $0.48 * *$ \\
\hline & 8 & 3 & 1 & - & 4 & 22 & 4 & 1 & 8 & 3 & $0.46 * *$ \\
\hline
\end{tabular}

- Lag: laggard; cm: c-mitosis; st: stickiness; cl: clumped chromosome; dis: disturbed chromosome; gran: granulated nucleus; frag: fragmented chromosome.

- ${ }^{* * *}$ Significantly different $(\mathrm{P}<0.01)$ from the control group
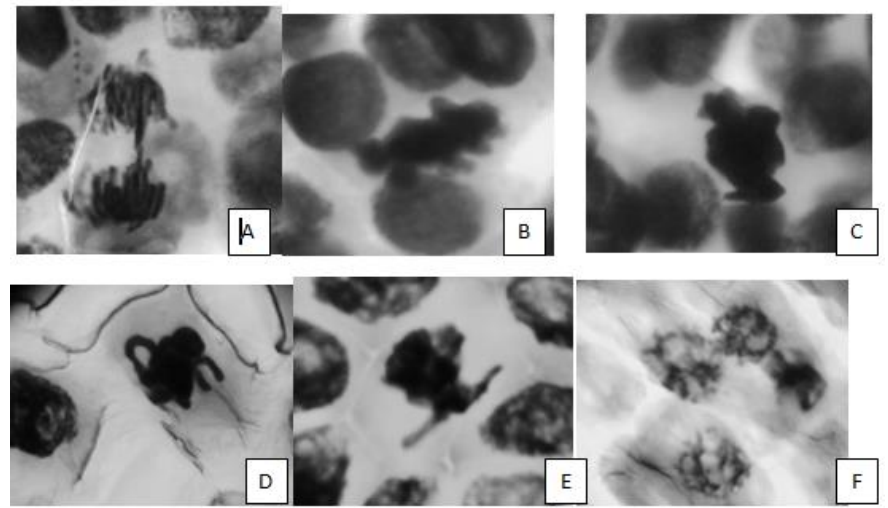

Fig. 1: chromosomal abnormalities found in cola treated Allium cepa root cells: A. chromosomal bridge; B\&C. sticky chromosomes; D. tied chromosome; E. deformed nucleus; F. erosive nucleus

Rayes (2008) studied the effects of histological and microbiological samples of commercial natural and artificial orange juices and cola-flavored soft drink. The results of the Cola soft drink showed that it is lethal Bifidobacterium bifidum and Lactobacillus acidophilus bacteria that cause a deleterious effects on the normal flora of the intestinal tract. The damage caused by soft drinks can be attributed to their various components and acidity $(\mathrm{pH} 3.5)$ since low $\mathrm{pH}$ can reduce the metabolic rate and the body's antioxidant defenses. The Allium cepa test is useful for many types of environmental samples and can be recommended as a tool for monitoring the genotoxic effects and thereby contributing to environmental risk assessment means (Rank, 2003).

\section{CONCLUSION}

Since toxigenicity and carcinogenicity results are linked together with our results, acritical dangerous is facing the consumers hence Cola soft drinks are very popular and worldwide. A creation of a similar soft drink without harmful substances will be a great achievement.

\section{REFERENCES}

[1] Adeyemo OA and Farinmade AE (2013). Genotoxic and cytotoxic effects of food flavor enhancer, monosodium glutamate (MSG) using Allium cepa assay. Afr J Biotechnol. 12(13): 1459-1466.

[2] Akinboro A, Mohammed K, Rathnasamy S, and Muniandy V R.(2011). Genotoxicity assessment of water samples from the Sungai Duariver in Pulau Pinang, Malaysia, using the Allium cepa test. Trop Life SciRes, 22(2): 23-35.

[3] Chan PC, Sills RC, Kissling GE, Nyska A, and Richter W (2008a). Induction of thyroid and liver tumors by chronic exposure to 2methylimidazole in F344/N rats and B6C3F1 mice. Arch Toxicol, 82(6):399-412.

http://dx.doi.org/10.1007/s00204-007-0249-7

[4] Chandraker SK, Singh P, and Pandey B (2014). Clastogenic effect of soft drink on root tip of Allium cepa. Int J Curr Microbiol App Sci, 3(5): 200-206

[5] ChoudhuryRC, and Palo AK. (2004). Modulatory effects of caffeine on methotrexate-induced cytogenotoxicity in mouse bone marrow. Environ Toxicol Pharmacol, 15(2-3): 79-85 http://dx.doi.org/10.1016/j.etap.2003.10.001

[6] Düsman E, Berti A P, Soares LC, and Vicentini VEP (2013). Cytotoxicity and mutagenicity of cola and grape flavored soft drinks in bone marrow cells of rodents. Food Sci Technol Campinas, 33(1): 122126. http://dx.doi.org/10.1590/S0101-20612013005000011

[7] Hannah C, Priya EJS, and Mammen A (2010). Duration dependent mutagenic study of Cola drinks on Allium cepa L. Biosci Biotechnol Res Asia, 7(2): 807-812

[8] Ito K, Nakazato T, Miyakawa Y, Yamato K, Ikeda Y, and Kizaki M (2003). Caffeine induces G2/M arrest and apoptosis via a novel p53dependent pathway in NB4 promyelocytic leukemia cells. $J$ Cell Physiol, 196: 276-283. http://dx.doi.org/10.1002/jcp.10289

[9] Jensdottira T, Bardowa A, and Holbrook P (2005) . Properties and modification of soft drinks in relation to their erosive potential in vitro. $J$ Dent, 33: 569-575. http://dx.doi.org/10.1016/j.jdent.2004.12.002

[10] Karaismailoglu MC. Investigation of the cytotoxic and genotoxic effects of Artemisia annua methanol extract with the Allium test.Ekoloji (2014). 23(91): 64-74. http://dx.doi.org/10.5053/ekoloji.2014.918

[11] Keast RSJ and Riddell L J. Caffeine as a flavor additive in softdrinks.Appetite.(2007) 49: 255-259. http://dx.doi.org/10.1016/j.appet.2006.11.003

[12] Khanna N and Sharma S (2013). Allium Cepa root chromosomal aberration assay: A review. Indian J Pharm Biol Res ,1(3):105-119.

[13] Milei J, Otero-Losada M, Gómez Llambí H, Grana DR, Suárez D, Azzato F, and Ambrosio G (2011). Chronic cola drinking induces metabolic and cardiac alterations in rats. World J Cardiol, 3:111-116. http://dx.doi.org/10.4330/wjc.v3.i4.111 
[14] Moon JK, and Shibamoto T (2011). Formation of carcinogenic 4(5)methylimidazole in Maillard reaction systems. J Agric Food Chem, 59(2): 615-618 http://dx.doi.org/10.1021/jf104098a

[15] National Toxicology Program ( NTP) (2007). Technical report on the toxicology and carcinogenesis studies of 4-methylimidazole in F344/N Rats and B6C3F1 Mice (Feed Studies).(CAS No. 822-36-6).

[16] National Toxicology Program (NTP) (2004). Toxicity Studies of 2- and 4-Methylimidazole Administered in Feed to F344/N Rats and B6C3F1 Mice. (CAS Nos. 693-98-1 and 822-36-6).

[17] Neelamkavil SV and Thoppil J E (2014). Toxicological evaluation of polar and nonpolar components of Isodoncoetsa (Lamiaceae). Turk $J$ Bot , 38: 252-257.

http://dx.doi.org/10.3906/bot-1306-4

[18] Otero-Losada ME , Loughlin SM, Rodríguez-Granillo G, Müller A, Ottaviano G, Moriondo M, Cutrin JC, and Milei J (2013). . Metabolic disturbances and worsening of atherosclerotic lesions in ApoE-/- mice after cola beverages drinking. Cardiovasc Diabetol , 12:57: 1-7. http://dx.doi.org/10.1186/1475-2840-12-57

[19] Rank J. The method of Allium anaphase-telophase chromosome aberration assay.Ekologija(2003). (Vilnius) 1: 38-42

[20] Rayes AAH (2008). Effect of some drinks on the benificial probiotic bacteria and the structure of testis of male albino mice. JAppl Sci Res, 4(7): 803-813.

[21] Sudhakar R, Gowda KNN, and Venu G (2001). Mitotic abnormalities induced by silk dyeing industry effluents in the cells of Allium cepa. Cytologia, 66: 235-239. http://dx.doi.org/10.1508/cytologia.66.235

[22] Wongkhantee S. Patanapiradej V, Maneenut C, and Tantbirojn D (2006). Effect of acidic food and drinks on surface hardness of enamel, dentine, and tooth-coloured filling materials. J Dent, 34: 214-220. http://dx.doi.org/10.1016/j.jdent.2005.06.003 